81'1:165

821.161.1.08-31 Пељевин В. О. https://doi.org/10.18485/sj.2020.25.1.24

МАРИНА В. КЕБАРА*

Универзитет у Крагујевцу

Филолошко-уметнички факултет
Оригинални научни рад

Примљен: 15. 10. 2019.

Прихваћен: 15. 01. 2020.

\title{
ЈЕЗИЧКО-СЕМАНТИЧКЕ И КОНЦЕПТУАЛНО-ПРАГМАТИЧКЕ АНОМАЛИЈЕ У РОМАНИМА ШЛЕМ УЖАСА И ЧАПАЈЕВ И ПРАЗНИНА ВИКТОРА ПЕЉЕВИНА**
}

Предмет истраживања у овом раду представља аномалност језичке концептуализације света, посматране на корпусу романа руског постмодернисте Виктора Пељевина Чапајев и Празнина и Шлем ужаса. Издвајамо и описујемо два вида језичких анамалија: 1) језичко-семантичке и 2) концептуално-прагматичке, као и њихове типове и подтипове, при чему оба вида укључују својства прагмасемантичких аномалија. Указивање на фукнционални статус поменутих аномалија у концептуализацији света представља примарни услов и циљ истраживања, те су оне анализиране искључиво као начин изражавања уметничке слике света у тексту а не као њен објекат. Лингвостилистичку анализу спроводимо са аспекта когнитивне, прагма и семиолингвистике, што условљава методолошки приступ, критеријум анализе и терминолошки систем у раду.

Кључне речи: језичка концептуализација света, језичко-семантичке аномалије, концептуално-прагматичке аномалије, Виктор Пељевин, Шлем ужаса, Чапајев и Празнина.

*m.kebara@filum.kg.ac.rs

** Рад је урађен у оквиру пројекта 178014: Динамика структура савременог српског јези$\kappa a$, који финансира Министарство просвете, науке и технолошког развоја Републике Србије. 


\section{1. УВОДНО ТЕОРИЈСКО-МЕТОДОЛОШКО РАЗМАТРАњЕ}

Аномалност језика, попут других система (социјалних, културних, семиотичких), повезана је са присуством одређеног стандарда, тј. са појмом норме у ширем смислу те речи. Према Радбиљу, „Языковая аномалия как отклонение от правил или норм вовсе не перечеркивает само правило или норму, а главное - оно может быть рационально мотивировано, коммуникативно адекватно, прагматически успешно и семантически осмыслено" (Радбиљ 2012: 9) ${ }^{1}$. У разматрању проблема аномалности у природном језику у поређењу са књижевним, у складу са Н. Д. Арутјуновом (Арутјунова 1990: 3-9), треба истаћи три чињенице: 1) да у природном језику не представља сваки логички противречан исказ језичку аномалију; 2) да су семантички противречни искази често законито укључени у текст природног језика; 3) да постоје искази који су прихватљиви и логички и семантички, а који истовремено стварају утисак аномалности због своје комуникативне, прагматичке неприхватљивости. Ослањајући се на речено, предмет истраживања у овом раду представља аномалност језичке концептуализације света у књижевном тексту на корпусу романа Чапајев и Празнина и Шлем ужаса руског постмодернисте Виктора Пељевина са задатком издвајања и описивања два вида аномалија, као и њихових типова и подтипова: 1) језичко-семантичких и 2) концептуално-прагматичких, при чему оба вида укључују својства прагмасемантичких аномалија. Анализу спроводимо искључиво посматрајући поменуте аномалије као начин изражавања уметничке слике света у тексту а не као њен објекат са циљем указивања на примарност услова њиховог функционалног статуса, будући да у тексту делују у својству базичног средства обликовања света, стила и текста уметничког приповедања. У оваквим условима губе потенцијално деструктиван карактер и стичу „прагматичку оправданост, функционалну сврсисходност и естетски значај” (Радбиљ 2012: 4). Језичка аномалност у Пељевиновом књижевном тексту у функцији је „кодификоване употребе језика” (Кебара 2019: 205), у чијој подлози су типични модели говорног понашања аномално употребљени у процесу језичке концептуализације слике света. Разни типови језичких аномалија укључени су у потенцијалну димензију дискурса, тумаченог на нивоу семиотичког простора у лингвостилистичкој анализи са аспекта когнитивне, прагма и семиолингвистике, што условљава методолошки приступ, критеријум анализе и терминолошки систем у овом раду. Вербални, често и невербални знаци „у својству су елемената поменутог кодовног система и усмерени су на управљање одговарајућом комуникативном сфером (...), превасходно са

${ }^{1}$ Језичка аномалија као одступање од правила или норме не поништава у потпуности само то правило или норму, и што је најважније, може бити рационално мотивисана, комуникативно адекватна, прагматички успешна и семантички осмишљена (нап. превела М. К.) 
одликама мита као прототекстуалне манифестације структурне основе Пељевиновог ауторског текста" (Кебара 2019: 205).

Језик у својој уметничкој употреби у одређеној је супротности са језиком у свакодневној комуникацији. Условно говорећи, логички су могућа два алтернативна становишта о статусу језичких аномалија у књижевном тексту у односу на аномалије језика у његовој свакодневној употреби: 1) Према првом становишту (Радбиљ 2012: 32), по својој ,језичкој суштини”, аномалије у природном језику не разликују се од многих тропа, стилских поступака и фигура у начину естетске употребе језика. Њихова разлика лежи само у сфери ауторске интенционалности (намерна или ненамерна употреба). Аналогно и по J. Д. Апресјану (Апресјан 1995: 598-621), многе стилске фигуре (нарочито метафоре и оксиморони), генерално се по својој унутрашњој структури у основи не разликују од језичких грешака. Још је античка реторика дефинисала фигуру као одступање од уобичајене, свакодневне употребе језика, чиме је „експлицитно указала на основни критериј фигуративности. То је отклон, удаљавање од уобичајеног, дакле нешто што је неуобичајено, што је реторички (пјеснички) еквивалент (и супституент) уобичајеном, тј. нефигуративном, непјесничком" (Ковачевић 2000: 91). Са ове позиције, језичка аномалност би могла да се тумачи као појава која се у књижевном тексту шири на практично било какву неузуалну употребу било које језичке јединице у њему. Ипак, она се може сузити тако да се не примењује на сва могућа неузуална језичка средства књижевног текста, будући да не води свака аномалија стилском поступку, и није сваки стилски поступак резултат језичке аномалности. У складу са Ковачевићем „може се рећи да је критериј одступања данас углавном прихваћен као нужан, али не и као довољан услов фигуративности. Јер, готово да је постигнута сагласност да већину фигура карактерише нека врста одступања, али и да свако одступање не твори фигуру” (Ковачевић 2000: 91).

2) Према другом становишту (Шмељов 1977, Винокур 1990, Горшков 2001), уопштено се може рећи да било која језичка појава књижевног текста који има уметничку мотивацију или барем рационалну интерпретацију, напротив, не може да се разматра као аномалија. То значи да језик уметничке књижевности укључује таква средства и начине изражавања, чија процена са становишта норми књижевног језика није довољна. Полазећи од оваквог тумачења, бројна језичка одступања у књижевним текстовима неће представљати аномалије, будући да одговарају ауторској слици света, па се сходно томе може извести закључак да у књижевном тексту, заправо, уопште нема аномалија. У складу са Радбиљем (Радбиљ 2012), сматрамо да би адекватност овог становишта могла да се потврди само под условом да оно не меша две различите појаве: језичку аномалност као принцип уметничког изражавања и језичку аномалност као њен објекат. Из тог разлога, као што смо напред већ навели, језичко-семантичке и концептуално-прагматичке аномалије у 
романима В. Пељевина анализирамо управо као средство језичке концептуализације света и начин изражавања одређене врсте свести, као и уметничке слике у књижевном тексту, а не као њен објекат, чиме се потврђује постојање и аутономност поменутих аномалија.

\section{2. АНОМАЛНОСТ ЈЕЗИЧКЕ КОНЦЕПТУАЛИЗАЦИЈЕ СВЕТА У КЬИЖЕВНОМ ТЕКСТУ ВИКТОРА ПЕЉЕВИНА}

Битно својство уметничког говора В. Пељевина у романима Чапајев $u$ Празнина и Шлем ужаса представља неразликовање говора наратора и говора јунака, услед чега настаје дилема да ли приповедање припада наратору или јунаку. У модусу стварност са аспекта реалног аутора, ствараоца текста, аномалија се може посматрати као намерна, док се с друге стране, у модусу текст аномалија у говору јунака, као структурног елемента композиционе организације приповедања, може сматрати ненамерном. Анализирају се три нивоа аномалне језичке концептуализације, који условно одговарају категоријама свет, језик и текст и сваком од њих приписује се одговарајући модални оквир као елемент метајезика њиховог описа.

\section{1. Језичко-семантичке аномалије у функцији концептуализације света у књижевном тексту Виктора Пељевина}

Издвајамо три типа језичко-семантичких аномалија уз опис њихових подтипова: 1) супстанцијалне (аномална језичка манифестација садржајних и структурних обележја објеката, веза и односа објективне стварности), 2) онтолошке (концептуализација садржајне компоненте прототипског света), 3) логичке (когнитивна, интерпретативна компонента прототипског света), при чему се „прототипски свет” одређује као корелат реалног света у концептуалном простору (Радбиљ 2012: 44-45). Будући да представљају аномалије у модусу свет а не у модусу језик, у уметничком говору аутора вербализоване су без очигледних системско-језичких нарушавања. Ипак, уочава се да је њихова језичка реализација у тексту праћена различитим врстама необичности у области контекстуалних ситуација, синтагматске реализације са аспекта компатибилности на нивоу опозиционог односа конкретност↔апстрактност, субјективност↔објективност, као и у форми аномалног исказа просторновременских и узрочно-последичних односа.

У примерима ${ }^{2}$ који следе указујемо на тип супстанщијалних аномалија као супстанцијализоване, материјализоване репрезентације апстрактне

\footnotetext{
${ }^{2}$ Све примере у овом раду истакла курзивом и подвукла М. К.
} 
семантике (у датим примерима: апстрактни концепти са семантиком мисли, семантиком емоције милосрђа, семантиком говора/речи), када аутор намерно приписује неадекватне предикате рационално осмишљеним субјектима, односно апстрактни концепти подвргнути су материјализацији:

(1) Лежи тако човек на леђима (...) и одједном скаче (...) и нестаје у непознатом правцу, само зато што се његова мисао (...) устремила некаквом насумичном маршрутом. (Пељевин 2017: 117-118)

(1a) Изјављује да његова мисао као да загриза, удубљује се у суштину сваке појаве. (Пељевин 2017: 120)

(1б) - А шта онда има? - Милост. - И шта још?

- Ништа. - Нешто не капирам - рече Шурик. - Шта, онда она као виси у празнини, та милост? (Пељевин 2017: 265-266)

\section{(1в) Organizam(-:}

Mala soba sa natpisom „Open GL” na zidu. Te reči postoje i u pravom sejveru, samo one tamo vise u vazduhu. A ovde su napisane masnom bojom na drvetu. Uzgred, šta to znači? (Пељевин 2006: 121-122)

Овај подтип аномалија у романима Пељевина у функцији је митологизације његовог наративног поступка и генерисан је из идентичне појаве у свакодневном говорном понашању, где се таквом стереотипном репрезентацијом концепт са апстрактним садржајем изражава као конкретно-осећајна представа. Управо овакви стереотипи у општејезичком систему чувају потенцијал фигуративног, материјализованог разумевања и митологизованог представљања стварности, што може постати принцип уметничког језика, а то и јесте битно својство Пељевиновог наратива.

У примерима (1г) и (1д) слика света на когнитивном нивоу укључује онтолошки аспект, преносећи садржај рефлектоване стварности уз употребу аномалије саме структуре света, када се реални предикат из модуса стварност нереално приписује инкомпатибилном субјекту (лице и уста се понашају као особе) или се поступак концептуализације заснива на прожимању онтолошког и логичког аспекта (пример 1д, у којем је истовремено аномално представљен и концепт узрочно-последичног односа):

(1г) ... Панел се одмаче у страну и из отвора је провирило мушко лице, такође јужњачког типа. Лище је нешто рекло, и Кавабата климну главом. (Пељевин 2017: 202)

(1д) $y_{c m a}$ која су стајала на бини нису се померала за време одговора, зато је он чинио брзе покрете истуреном задњицом. (Пељевин 2017: 295) 
У примерима (1ђ), (1e),(1ж) и (13) нарушава се логички план аномалним начином и формом менталне интерпретације стварности. Овакве логичке аномалије резултирају неинформативним исказима неразумљивим учесницима дијалога, доводећи до таутолошке сувишности (редудантности) или инкомпатибилности концепата на нивоу каузалних односа засниваних на успостављању лажних узрочно-последичних веза, као и односа обавезности, погодбености (кондиционалности):

(15) Ariadna

„Glavna tajna Asteriosa jeste u tome što je on apsolutno nepotreban. On je stražar koji nepotkupljivo čuva ono što je sam stvorio od onoga što je sam stvorio...." (Пељевин 2006: 154)

(1e) Nutscracker

Organizme, a kako si saznao da je centar lavirinta tamo gde je ogledalo sa stolicom?

\section{Organizam(:}

Po samom ogledalu sa stolicom. Zašto bi se oni inače tamo nalazili?

\section{Monstradamus}

Jasno. (Пељевин 2006: 122-123)

(1ж) Не - рекао је шкиљећи у Аристотелову бисту - ако хоћеш да једном изађеш одавде, треба да читаш новине и да притом нешто осећаш. (Пељевин 2017: 105)

(13) Romeo-y-Cohiba

To je tvoj RR SUV.

\section{Isolda}

Zašto?

\section{Romeo-y-Cohiba}

On je sa tvoje strane.

\section{Isolda}

Ali u njemu si ti. Znači, on je tvoj.

\section{Romeo-y-Cohiba}

Kako može biti moj ako ga ja ne vidim? (Пељевин 2006: 109)

Описаним аномалијама нарушен је модални оквир правилног, адекватног начина расуђивања и размишљања о свету 'Људи сматрају да је могуће тако размишљати/исправно размишљати и расуђивати'. Битно је истаћи да употребљене логичке аномалије у горе наведеним примерима не представљају психолошки или естетски (по жанровским законима) мотивисано одступање наратора или јунака од рационално-логичке интерпретације света.

У примерима (1и), (1j) и (1к) уочен је подтип логичких аномалија са немотивисаним логичким изокретањима у уметничком говору, заснован на 
споју нескладних, инкомпатибилних концепата попут нарушавања формално логичких закона идентитета (борци у Валхали $\rightarrow$ бикови у индустрији меса), контрадикиије, каузалности, што доводи до апсурда и неразумевања међу саговорницима у бесмисленом дијалогу:

(1и) - Бории, а? - рече Барон. - Ко све неће доспети у Валхалу. Серјожа Монголоид... А све то због идиотског правила о мачу у руци.

Шта им се десило? - упитах

- Оно што треба - рече барон. (...)

- Изгледа да ће бити бикови у индустрији меса. Сада се често тако повлађује. Делимично због бескрајног Будиног милосрђа, а делимично зато што Русији стално фали меса. (Пељевин 2017: 234)

(1j) Моја повест још од детињства је прича о томе како бежим од људи, (...) схватате?

- Разуме се - (..) Прво говорите како сте дошли до свог садашњег стања заједно с другима, а затим да бежите од људи (Пељевин 2017: 44-45)

(1к) Ariadna

Čula sam da ako čovek zna, to je upravo zato što je dobar.

Nutscracker

A ja sam čuo da ako je dobar, onda je to upravo zato što zna.

Organizam(:

A šta se to nas tiče. (Пељевин 2006: 160)

У примерима ниже истакнута је логичка имплицитна контрадикторност испољена на когнитивном нивоу (расуђивање и размишљање о свету), а настаје када се значење актуелизоване јединице нађе у супротности са подразумеваним значењем већ постојећим у интенционалној сфери говорника. У примеру (1л) постоји контрадикција између плана говорне намере и плана његове вербалне реализације: из контрадикторности става 'наше време је постало страшно управо због свих оних који стреме слободи' закључује се да је јунак (Чапајев) имао на уму супротно ономе што је речено. У примерима $(1 љ),(1 \mathrm{M}),(1 \mathrm{H})$ и $(1 \mathrm{њ})$ аномална актуелизација деиктичких показатеља и квантификаторских речи резултира нарушавањима у области говорне организације и референцирања. Ова аномалија доводи до контрадикторне актуелизације параметара догађаја и објеката реалног света, на које упућују деикса и квантификатори у примерима, а у функцији су митологизације света у Пељевиновом књижевном тексту:

(1л) - Хоћу да наздравим - рече Чапајев, (...) - овом страшном времену у коме смо морали да се родимо и живимо, и свима онима који у том времену не престају да стреме слободи. (Пељевин 2017: 96) 
1љ) Зато што се он налази на месту којег нема. Разумете. Он се налази нигде. (Пељевин 2017: 242)

\section{(1м) Ariadna}

Idemo dalje. Pitanje:

„Kako sve može da nastane ni iz čega?"

Sledeće pitanje:

„Kako šlem užasa može da se nalazi unutar svog sopstvenog dela?”

Odgovor:

„Šlem užasa cepa ono jedino što postoji na mnoštvo onoga čega nema. (Пељевин 2006: 160)142-143)

(1н) Како да се постане он? (...)

О томе се и ради да је једини начин да постанеш четврти тај да престанеш да будеш сви други.

- Шта то значи, треба постати нико? (Пељевин 2017: 280)

(1њ) Седео је испред ватре исправивши леђа и гледајући право испред себе, али (...) било је јасно да он не гледа у њих, већ баш нигде. (Пељевин 2017: 281)

За разлику од језика свакодневне комуникације, у којем се у пресупозитивном делу исказа изоставља оно што је разумљиво само по себи у циљу успешне комуникације, у уметничком говору Пељевина рефлектованом у горе наведеним примерима, у складу са принципом онеобичавања, суштинским обележјем његовог наративног поступка, управо оно што се само по себи разуме сматра се необичним, подлежним верификацији и редудантној вербализацији. У подлози описаног поступка налазе се прагмасемантичке аномалије засниване на нарушавању „принципа унутрашње доследности” (Апресјан 1990) говорника током изражавања, услед чега се добија неправилан и алогичан исказ. Оваквим уметничким поступком Пељевин генерише језичку и семиотичку игру, стварајући савремени неомит на основу постојећег семантичког обрасца.

\section{2. Концептуално-прагматичке аномалије у функцији концептуализације света у Пељевиновом књижевном тексту}

Према Радбиљу (Радбиљ 2012: 136), аномалност као начин уметничког говора може да се посматра двојако: а) на нивоу самог устројства уметничког света (неправилан свет), б) на когнитивном нивоу као менталне аномалије у сфери мишљења о свету (језик мисли). Концептуалне аномалије у уметничком говору представљају одступања испољена током преласка са језичког система на његову текстуалну реализацију путем вербализације аномалних процеса 
у области мишљења. Када се оваква вербализација испољи у току говорног понашања, услед чега долази до нарушавања норми и принципа вербалне комуникације, говорних чинова и стратегија, настају конщептуално-прагматичке аномалије, које за своје препознавање и тумачење захтевају упућивање на контекст или ванјезичке информације. Нарушавање говорног понашања и комуникативног чина у Пељевиновом књижевном тексту уочено је у сфери мотивационо-прагматичких ставова, комуникативне потребе и илокуционе снаге и превасходно је повезано са интенционалном сфером говорника, односно аномалном мотивацијом комуникативног чина. Аномалност се рефлектује у томе што мотиви због којих јунаци у књижевном тексту Пељевина покрећу своју говорну активност немају никакве везе са прототипским мотивацијама говорног понашања у свакодневној комуникацији или, пак, учесници дијалога као свој комуникативни циљ нису поставили поруку или утицај на примаоца, већ објашњење садржаја света самог по себи. Аналогно језичко-семантичким, и коцептуално-прагматичке аномалије у подлози су својства митологизираности Пељевиновог уметничког говора у анализираним романима.

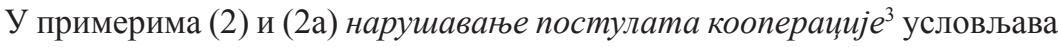
неуспешну комуникацију у којој учесници користе исте речи у различитим значењима, па у језику мисли један од учесника у дијалогу у пресупозитивној компоненти семантике лексема баук и лептир има у виду (подразумева) пренесено значење, док други исто то значење преводи на буквални план:

(2) Када сам бежао, пуцао сам. Ти разумеш да сам пуиао у страх саткан oд сопствених баука, али у Гороховој се то не може објаснити. (...) они би свакако питали - а зашто ви у ствари пуцате по бауцима? Шта, зар се то вама не свиђају бауии који круже Европом? (Пељевин 2017: 18)

(2a) - Еx, Пећка - рече Чапајев - познавао сам једног кинеског комунисту по имену Це Чуан. Он је често сањао (...) да је ирвени лептир (...) и када се будио, није могао да схвати да ли то лептир сања да се бави револуционарним радом, или то илегалац сања да лети кроз цвеће. (...) Пошто га је испитивао барон Јунгерн, (...) следеће питање је било зашто је тај лептир за комунисте. А овај је рекао да он уопште није за комунисте. Онда су га питали зашто се у том случају лептир бави илегалним радом. (Пељевин 2017: 223-224)

У примерима (2б) и (2в) тип прагмасемантичке аномалије комуникативног чина изражен је контрадикцијом која настаје инкомпатибилним повезивањем пресупозитивне компоненте семантике предикативне речи ( $u \hbar u$,

${ }^{3}$ Падучева (2010: 236), у складу са Грајсом, издваја четири групе комуникативних постулата: 1) постулат информативности; 2) постулат истинитости; 3) постулат релевантности; 4) постулат јасности исказа. 
даровати, доћи/долазити), која садржи обавезну пресупозицију 'примењује се на људе', и лексичког значења друге речи у синтагматском споју, док се у примерима (2г) и (2д) испољава тип аномалности условљен контрадикторном интенционалношћу у подлози аномалног исказа у 1 . лицу субјекта говора који није жив, што у прототипском свету није могуће:

(2б) - Мало даље (...) - настављао је Кавабата - скрећемо удесно, и ево, у сусрет нам иду врата која Дарују Светлост... (Пељевин 2017: 197)

(2в) Па Володин је говорио да ћемо ми од себе бежати кроз шуму кад $\underline{\partial \circ y}$ печурке.

- А, капирам. Слушај, а што се то тако каже - дођу, долазак? Одакле оне уопште долазе?

- Је л’ ти то мене питаш? - упита Володин. (Пељевин 2017: 263)

(2г) - Ко сте ви? - упита барон.

- Борци Серјоже Монголоида - рече један од њих не подижући се.

- Како сте доспели овамо? - упита барон.

- Грешком су нас убили, команданте.

- Нисам ја ваш командант - рече барон. - А грешком никог не убијају.

- Стварно су грешком - жалосно рече други. - У сауни. (Пељевин 2017: 234)

(2д) - Да - рече барон. (...) Некада сам био њихов командир.

- Шта, заједно сте се борили?

- Да - рече барон - и то. (...) У своје време заједно су нас стрељали

у Иркутску... (Пељевин 2017: 244)

За разлику од горе наведених прагмасемантичких аномалија, где долази до супротстављања конвенционалне и неконвенционалне компоненте значења, у примерима (2ち) (2e) и (2ж) као начин уметничког изражавања употребљене су комункативно-прагматичке аномалије, у којима се сукобљавају само неконвенционалне компоненте значења. Таква одступања граде аномалан комуникативан чин као производ таутолошки бесмислене и илокуционо немотивисане дијалошке интеракције јунака, што је суштинска одлика апсурда и нонсенса, битног својства Пељевиновог уметничког говора у анализираним романима. У овим примерима апсурдност, бесмисленост дијалога, па сходно и неразумевање међу саговорницима постиже се концептуалном алогичношћу аномално употребљених прототипских модула. Тако, у примеру (2ђ) алогичност се рефлектује у аномално употребљеном прототипском модулу 'реално егзистирајући ентитет (изражен лексемом трон) не може истовремено да постоји у непостојећем простору', израженом лесемом место у синтагми „налази се на месту којег нема” и егзофоричном деиктичком речју нигде, док се у примерима (2e) и (2ж) апсурдност дијалога постиже алогичном употребом 
модула-прототипа 'ти не може да буде истовремено $j a$ ' (пример 2е) и 'неко не може истовремено да буде нико' (пример 2ж) према моделима-прототипима $X$ не може истовремено да буде $Y$ и $X$ не може истовремено „да буде”/да постоји и да ,престане да буде”/ да престане да постоји:

(2ђ) Што је најважније, трон (...) по правилу припада сваком човеку. Али готово је немогуће попети се на њега зато што се налази на месту којег нема. Разумете? Он се налази нигде. (...) А зашто се ви не бисте нашли у том „нигде” за живота? (...) После тога, (...) неће остати ништа, чак ни „нигде”. (Пељевин 2017: 242)

(2е) - Гле, кад оно - то није он, него ти. А треба да пуцаш. Е, (...) је л’ од тога може да се пукне?

Може.

- А кад пукнеш, онда није блам ни да се да гас?

- Ето, испада да ћеш бежати од себе. Капираш?

- Не - рече Кољан након паузе - не капирам. Ако то није он, него ја, где сам онда ја?

- Ти и јеси он.

$-\underline{\mathrm{A} \mathrm{OH}}$ ?

- А он је ти.

- Ништа не капирам - рече Кољан. (...) (Пељевин 2017: 260-262)

(2ж)- Не можеш лепо да кажеш како да постане он? (...)

- О томе се и ради да је једини начин да постанеш четврти тај да престанеш да будеш сви други.

- Шта то значи, треба постати нико?

- Треба дапрестанеш и да будеш нико. Треба у исто време да будеш нико и да престанеш да будеш нико, разумеш? (Пељевин 2017: 280)

Нарушавање комуникације у Пељевиновом књижевном свету нонсенса (посебно у роману Шлем ужаса, који готово у целини представља концептуализацију апсурдног света), може да буде узроковано разликама у моделима света, односно разликама у тумачењу света. Свет нонсенса својом хаотичношћу на површинском нивоу језичке концептуализације добија се од прототипског света преласком у контрадикторности или негацију путем елементарних трансформација супституцијом и инверзијом, када се замењује или инвертира нормалан редослед догађаја:

\section{(23) Ariadna}

Patuljak je napisao svoj odgovor čak brže nego što sam ja završila sa pitanjem... (Пељевин 2006: 144)

(2и) Ariadna

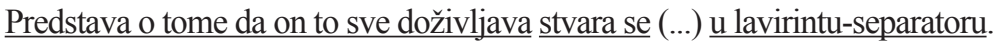




\section{Nutscracker}

Od čega se stvara?

\section{Ariadna}

Ni od čega. Trebalo je da slušaš. (Пељевин 2006: 62)

(2j) Nutscracker

A umesto glave ima šlem užasa?

\section{Ariadna}

Da.

\section{Nutscracker}

Ispada da se šlem užasa pojavljuje u lavirintu-separatoru koji se nalazi u istom tom šlemu? (...) Ali šlem je veći od samo jednog svog dela. Kako može da se nalazi u svom delu? (...) odnosno, u svakom slučaju dolazimo do toga da šlem užasa nastaje u jednom od svojih delova. A postoji u drugom. Gde je tu zdrava logika?

\section{Ariadna}

Kako gde? U rogovima izobilja.

\section{Nutscracker}

Arijadna, je 1' ti to ozbiljno? (Пељевин 2006: 62-63)

\section{(2к) UGLI 666}

Krcko, ja iz tvoje priče nikako ne mogu da razumem jednu stvar. Kako se može neprimetno zameniti ono što je čoveku pred očima? Kao da on gleda u jedno mesto, a vidi drugo, i ništa ne primećuje?

\section{Nutscracker}

Ni ja to u početku nisam mogao da shvatim. Ali za Šlemila to „zameniti” nema nikakvog smisla. U životu ono što vidite zavisi od toga kuda gledate. A kada imate šlem, sve je suprotno - ono kuda gledate zavisi od onoga što vidite. Je li ti jasno?

\section{UGLI 666}

Ne baš sasvim. (Пељевин 2006: 71)

Неусаглашеност модела света међу учесницима дијалога настаје као последица игре концептима на нивоу бинарних опозиција универзалност $\leftrightarrow$ посебност, а у оквиру њих опозиција регуларност ↔ нерегуларност, nараметричност $\leftrightarrow$ непараметричност, што резултира непотпуном комуникацијом, збуњеношћу и неразумевањем међу саговорницима. Оваквим начином језичке концептуализације поступком онеобичавања у свом књижевном тексту Пељевин ствара необичан уметнички свет као производ игре језичке свести у моделирању објективне стварности, указујући на чињеницу да заправо људска свест ствара многобројне светове, чије је постојање изоловано од субјекта немогуће. 


\section{3. ЗАКЉУЧНЕ НАПОМЕНЕ}

Предмет истраживања у овом раду је аномалност језичке концептуализације света анализирана на корпусу романа руског постмодернисте Виктора Пељевина Чапајев и Празнина и Шлем ужаса. Класификовали смо два вида језичких аномалија са њиховим типовима и подтиповима: 1) језичко-семантичке и 2) концептуално-прагматичке, при чему оба вида укључују својства прагмасемантичких аномалија. Анализа је показала следеће:

3.1. У оквиру језичко-семантичких аномалија издвојили смо и описали три типа: а) супстанцијалне, б) онтолошке, в) логичке аномалије. Унутар поменутих типова анлизирали смо и описали следеће подтипове:

3.1.1. Аномалност супстанцијализоване, материјализоване репрезентације апстрактне семантике, када аутор намерно приписује неадекватне предикате рационално осмишљеним субјектима (примери 1, 1а, 1б, 1в).

3.1.2. Аномалије са прожимањем онтолошког и логичког аспекта где се реални предикати из модуса стварност нереално приписују инкомпатибилном субјекту, уз истовремено аномално представљање концепта узрочно-последичног односа (примери 1г, 1д).

3.1.3. Подтип логичких аномалија одражен у аномалном начину и форми менталне интерпретације стварности уз испољавање таутолошке сувишности (редудантности), инкомпатибилности концепата каузалних односа, контрадикиије или нарушавања формално логичких закона идентитета (примери 1ђ, 1е, 1ж, 1з, 1и, 1ј, 1к).

3.1.4. Аномалије са логичком имплицитном контрадикторношћу где се значење актуелизоване јединице налази у супротности са подразумеваним значењем већ постојећим у интенционалној сфери говорника (примери 1л,1љ, $1 \mathrm{M}, 1 \mathrm{H}, 1 \mathrm{~m})$.

Описаним аномалијама, као начином уметничког говора, Пељевин гради слику света у којој се преплићу концепатске опозиције, у складу са принципом онеобичавања као суштинским својством његовог наративног поступка. На тај начин, репрезентује алогичну и хаотичну стварност, рушећи елементаран поредак ствари у циљу успостављања уметничког митологизма као једног од типова симулације митолошке свести у парадигми културног менталитета постмодернизма.

3.2. Концептуално-прагматичке аномалије представљају нарушавање норми и принципа вербалне комуникације, говорних чинова и стратегија у сфери мотивационо-прагматичких ставова, комуникативне потребе и илокуционе снаге. Попут претходних, истовремено укључују и својства прагмасемантичких аномалија. Издвојени су и описани следећи типови: 
3.2.1. Нарушавање комуникативних постулата коопераиије, што резултира неуспешном комуникацијом (примери 2, 2a).

3.2.2. Прагмасемантичке аномалије комуникативног чина испољене у контрадикцији услед инкомпатибилног повезивања пресупозитивне компоненте семантике једне речи и лексичког значења друге (примери 26 и 2 в) или контрадикторном интенционалношћу у подлози аномалног исказа (примери 2г и 2д). У овом типу аномалија долази до супротстављања конвенционалне и неконвенционалне компоненте значења.

3.2.3. Комункативно-прагматичке аномалије у којима се сукобљавају само неконвенционалне компоненте значења. Резултирају аномалним комуникативним чином услед таутолошки бесмислене и илокуционо немотивисане дијалошке интеракције јунака, градећи апсурд и нонсенс, битно обележје Пељевинових романа. Неразумевање међу саговорницима постиже се концептуалном алогичношћу аномално употребљених прототипских модула (примери 2ち, 2е, и 2ж).

3.2.4. Аномалије узроковане разликама у моделима света као средство концептуализације света нонсенса и апсурда путем контрадикторности или негације прототипског света употребом супституције и инверзије (примери $23,2$ и, $2 \mathrm{j}, 2 \kappa)$.

Описане аномалије одлика су поступка онеобичавања којим Пељевин у свом књижевном тексту ствара необичан уметнички свет. Аномалност његовог уметничког говора резултат је субјективизације испољене у онтологизацији значења, односно брисању разлика на плану стварности и плану његове менталне концептуализације, што се очитује у обједињавању у нерашчлањену целину општих концепата простора и времена, узрока и последице, те се принцип аномалности успоставља као једино могућ.

\section{ИЗВОРИ}

Пељевин 2006: Viktor Peljevin, Šlem užasa (kreativ o Tezeju i Minotauru), Beograd: Geopoetika.

Пељевин 2017: Виктор Пељевин, Чапајев и Празнина, Београд: ЛОМ.

\section{ЛИТЕРАТУРА}

Апресјан 1990: Ю. Д. Апресян, Языковые аномалии: типы и функции, Res Philologica: Филологические исследования, Памяти академика Георгия Владимировича Степанова (1919-1986), Под ред. Д. С. Лихачева, Москва: Наука, 50-71. 
Апресјан 1995: Ю. Д. Апресян, Языковая аномалия и логическое противоречие, Избранные труды, В 2 томах, Москва: Языки русской культуры, 1995, Т. II: Интегральное описание языка и системная лексикография, 598-621.

Арутјунова 1990: Н. Д. Арутюнова, Логический анализ языка: Противоречивость и аномальность текста, Сб. научн. Трудов, ИЯ АН СССР, Отв.ред. Н.Д. Арутюнова, Москва: Наука, 1990, 3-9.

Винокур 1990: Г. О. Винокур, Филологические исследования: Лингвистика и поэтика, Москва: Наука.

Горошков 2001: А. И. Горшков, Русская стилистика: Учеб. Пособие, Москва: Астрель-АСТ.

Кебара 2019: М. Кебара, Језичка слика света и концептосфера у роману 'Шлем ужаса' Виктора Пељевина, у: М. Лончар-Вујновић (ред.), Наука без граница II (међународни тематски зборник): 4, Пејзажи ума, Косовска Митровица: Филозофски факултет Универзитета у Приштини, 201-218.

Ковачевић 2000: М. Ковачевић, Стилистика и граматика стилских фигура, Крагујевац: Кантакузин.

Радбиљ 22012: Т. Б. Радбиль, Языковые аномалии в художественном тексте: Андрей Платонов и другие, Монографиая, 2-е издание, стереотипное, Москва: Флинта.

Падучева 22010: Е. В. Падучева, Семантические исследования, семантика времени и вида в русском языке, семантика нарратива, второе издание, исправленное и дополненное, Москва: ЯЗЫКИ СЛАВЯНСКОЙ КУЛЬТУРЫ.

Шмељов 1977: Д. Н. Шмелев, Русский язык в его функциональных разновидностях, Москва: Наука. 


\title{
ЯЗЫКОВО-СЕМАНТИЧЕСКИЕ И \\ КОНЦЕПТУАЛЬНО-ПРАГМАТИЧЕСКИЕ АНОМАЛИИ \\ В РОМАНАХ ШЛЕМ УЖАСА И ЧАПАЕВ И ПУСТОТА \\ ВИКТОРА ПЕЛЕВИНА
}

\author{
Резюме
}

Предметом исследования в данной работе является аномальность языковой концептуализации мира, рассматриваемая на корпусе романов русского постмодерниста Виктора Пелевина Чапаев и Пустота и Шлем ужсаса. Мы выделили и описали два вида языковых аномалий: 1) языково-семантические и 2) концептуально-прагматические, а также их типы и подтипы, причем оба вида включают в себя свойства прагмасемантических аномалий. Нами был проведен лингвостилистический анализ с точки зрения когнитивной, прагматической и семиолингвистики, что обусловило методологический подход, критерий анализа и терминологическую систему в работе. В рамках языково-семантических аномалий мы определили и описали три типа: а) субстанциональные, б) онтологические, в) логические аномалии, и в пределах указанных выше типов мы проанализировали их подтипы. Внутри концептуально-прагматических нами было определено и описано четыре типа, существенная особенность которых заключается в том, что они включают в себя свойства прагмасемантическиких и коммуникативно-прагматических аномалий.

Ключевые слова: языковая концептуализация мира, языково-семантические аномалии, концептуально-прагматические аномалии, Виктор Пелевин, Шлем ужаса, Чапаев и Пустота. 